\title{
Erratum to: Methodology of Judicial Proof and Presumption
}

\author{
Erratum to: \\ J. He, Methodology of Judicial Proof and Presumption, \\ Masterpieces of Contemporary Jurisprudents in China, \\ https://doi.org/10.1007/978-981-10-8025-8
}

In the original version of the book, the section numbering has been changed from Roman numerals (I, II, III, IV ...) to Arabic numerals $(1.1,1.2,1.3,1.4 \ldots$ ) in all the chapters. The erratum book has been updated with the change.

The updated online version of this book can be found at https://doi.org/10.1007/978-981-10-8025-8 